AperTO - Archivio Istituzionale Open Access dell'Università di Torino

\title{
Exploring the link between patronage and party institutionalization: An historical-institutional analysis of the Italian transition
}

\section{This is the author's manuscript}

Original Citation:

Availability:

This version is available http://hdl.handle.net/2318/1622362

since 2018-03-14T12:57:55Z

Published version:

DOI:10.1080/13510347.2013.764286

Terms of use:

Open Access

Anyone can freely access the full text of works made available as "Open Access". Works made available under a Creative Commons license can be used according to the terms and conditions of said license. Use of all other works requires consent of the right holder (author or publisher) if not exempted from copyright protection by the applicable law. 
This is the author's final version of the contribution published as:

Di Mascio, Fabrizio. Exploring the link between patronage and party institutionalization: An historical-institutional analysis of the Italian transition. DEMOCRATIZATION. 21 (4) pp: 678-698.

DOI: $10.1080 / 13510347.2013 .764286$

The publisher's version is available at:

http://www.tandfonline.com/doi/pdf/10.1080/13510347.2013.764286

When citing, please refer to the published version.

Link to this full text:

http://hdl.handle.net/2318/1622362 


\section{INTRODUCTION}

Since the mid1990s the "cartel party" approach has become one of the ruling models in the comparative politics literature (Katz and Mair 2009). In this influential analysis, the parties' traditional role as intermediaries between society and public institutions have become increasingly less relevant, a pattern redressed organizationally through the intensification of the relationships with the state, which have assumed increased importance in terms of both legitimacy and resources to maintain their position within contemporary democracies. The reinforcement of the linkages between parties and the state should be understood in the context of an ideational transformation by which parties have gradually come to be seen as public service agencies which are part of the state apparatus rather than private institutions which act as the agents of social segments (Biezen 2004).

Yet, notwithstanding the prominence of the approach, it is surprising that the relationships between parties and the state have been analyzed rather unsystematically. In this regard, the analytical framework proposed by Biezen and Kopecky (2007) allows to assess more precisely the dimensions of the party-state symbiosis highlighting important differences in the three basic types of linkages between parties and the state: dependence of parties on the state; management of parties by the state; control of the state by parties. While recent studies of European political parties have produced evidence on the first two types of partystate linkage (Biezen 2008), the last dimension have thus far been underinvestigated. This is probably due to the difficulty of studying the control of the state by parties, with the challenges being both conceptual and empirical as the politicization of the state involves complex and covert phenomena (Müller 2000).

Patronage, conceptualized as the power of parties to appoint people in state positions (Kopecky and Scherlis 2008), is a valuable indicator for measuring the control of the state by 
parties. In particular, patronage has been a key resource serving to shore up South European party organizations (Ignazi and Ysmal 2008). Processes of party permeation of public bodies have been facilitated by the character of South European bureaucracies at the inception of party competition. In contrast to other West European democracies, South European bureaucracies did not develop into fully consolidated Weberian administrations before the transition to democracy (Gunther et al. 2006). Indeed, such weak state structures lacked the professional autonomy and legitimacy to resist the encroachment of political elites attempting to control the state to entrench their position as the dominant actors of democratic processes after authoritarianism (Morlino 1998). Consequently, efforts to modernize South European administrations were aborted during the consolidation of democracy, generating patterns of extensive politicization "at the top" of higher administrative ranks and enduring clientelistic personnel recruitment "at the bottom" of public agencies (Sotiropoulos 2004).

Among South European democracies, Italy has long been characterized by one of the highest levels of party colonization of the State in comparative perspective (Muller 2000). As pointed out by Cassese (1993), an administrative system lacking an administrative elite (well-educated civil servants selected by competitive means sharing an esprit de corps and enjoying high social esteem) has resulted from historical development in Italy where public administration has been used as a social buffer providing employment to the underdeveloped South, eventually reflecting its backwardness. Thus, in Shefter's terms, the Italian administrative system displayed a low level of "bureaucratic autonomy" as civil servants had no authority towards the public nor did they benefit from public support. This implied that the control over such weak state structures inherited from the fascist regime enabled the governing coalitions dominated by the DC to distribute a huge quantity of 
public resources as selective benefits (Cassese 1993). Both the occupation of top state posts in the fragmented mélange of state agencies and companies and the distribution of jobs at all levels of government primarily directed at rewarding party supporters and voters have been extensively documented by the literature (Golden 2003). The party colonization of the state has led to exceptional levels of corruption paving the way to the massive eruption of scandals in the early 1990s, eventually generating a dramatic party system breakdown that can be regarded as a crisis triggering a rather uncommon transition from a democratic regime best defined as a "partitocrazia" (one dominated by political parties) to another regime, equally democratic but not fully consolidated (Pasquino 1997).

Whereas democratic consolidation implied the party colonization of the Italian state, the impact of early 1990s' transition on patronage practices has remained largely unexplored. The aim of the paper is not only to shed light on patterns of patronage in Italy after the collapse of the old partitocrazia but also to search for explanations by emphasizing the influence of institutional legacies and temporality of party system restructuring on the trajectory of patronage in Italy. As revealed by the recent advent in late 2011 of the purely "technical" government lead by Mr Monti and composed of non-partisan professionals precisely because previous party governments proved unable to devise any reform to prevent and counteract the dramatic effects of the global economic downturn, the performance in government of the new Italian parties has been far from the expectations generated by the earlier crisis of the old partitocrazia.

As in the 1992 economic crisis, once again the management of the increasing financial pressures has been entrusted to a technical government. This means that throughout the last two decades (1992-2011) the new Italian political class has been incapable of consolidating a durable party government regime. Yet, the Italian transition prompted by 
the early 1990s crisis seemed to have initiated deep processes of reform at both the party and the state level. Concerning the latter, the European pressures for reform greatly intensified with the membership of the EMU acting as a powerful external constraint (Dyson and Featherstone 1996) that imposed stricter budget obligations for state structures and the streamlining of the huge galaxy of state-owned enterprises at the central level. Conversely, the decentralization process has reinforced the powers and functions of the subnational executives generating significant growth in terms of local public agencies and companies (Citroni 2009). With regard to the former, the party system "atomization" that followed the old "polarized pluralism"(Sartori 1976) in the period 1992-1994 has given way to a peculiar bipolarism marked by the wholesale alternation in government of fragmented pre-electoral coalitions which has been stimulated by the adoption of two major electoral reforms. However, in a context of democratic malaise characterized by the deep popular disaffection towards party organizations party labels failed to stabilize generating an everchanging party format (Baldini 2011). Given the weakness of party loyalties, the new Italian parties have displayed similarities with parties in new democracies marked as they have been by an high level of personalism and dominance from a small centre of power located at the intersection of the party in government and the party in central office (Bosco and Morlino 2006; Ignazi et al. 2010).

This research draws on democratization literature which emphasizes the contribution of political parties to successful democratic consolidation, and in that context the importance of party institutionalization (Gunther and Diamond 2003; Mainwaring and Torcal 2006). This concept has been firstly applied to political parties by Huntington (1968) who discussed institutionalization more broadly as the process by which organizations and procedures acquire value and stability. An analogous concept has been proposed by Panebianco (1988) 
who focused just on parties and defined institutionalization as the way parties organizations solidify slowly losing their character as a tool. As pointed out by Levitsky (1998), these two accounts share the notion of institutionalization as "value infusion" (Selznick 1957). However, when it comes to elaborating the concept, they identified different structural dimensions of institutionalization. As noted by Morlino (1998), the disagreement about the structural dimensions of institutionalization is due to the multi-dimensional nature of the concept riddled as it is with ambiguities and tensions. Drawing on Randall and Svasand (2002), who identified a set of core elements of the concept, I understand institutionalization as the process by which parties become established in terms both of integrated patterns of behavior and of attitudes. This means taking the elements of systemness (the increasing scope, density and regularity of the interactions that constitute the party as a structure), decisional autonomy from external interference, value infusion and party reification in the popular imaginary as the key aspects of the party institutionalization process.

The remainder of this paper will show that patterns of limited change in patronage practices have greatly contributed to hindering the institutionalization of the new Italian parties as organized actors capable to support effective governmental policy coordination. In doing so, the analysis draws on historical institutionalism that now constitutes a well established approach in the broader comparative politics literature (Immergut and Anderson 2008) while being still largely neglected in contemporary party research.

The article proceeds as follows. First, I review the comparative research on patronage politics in order to sketch three alternative scenarios on the development of political appointments in Italy after the collapse of the old party system. Then, I discuss the methodology and data used in this study. I next turn to the empirical analysis highlighting 
the extreme personalization of appointment processes within state institutions that display still high levels of politicization. The final section discusses the main findings and formulate some elements for a future research agenda.

\section{RESEARCH FRAMEWORK}

Most literature conceives of patronage as a direct and particularistic distribution of public resources in exchange for some form of political support (Müller 2000). As such, patronage and clientelism are largely synonymous and are used interchangeably to define citizenpolitician linkages through selective material incentives in networks of direct exchange (Kitschelt and Wilkinson 2007). However, in a subset of the literature there is an important distinction between patronage and clientelism (Hicken 2011). Some authors define patronage narrowly as the power of political leaders to exchange public sector jobs for political support, whereas clientelism includes not only jobs but also other state resources which are traded for electoral support (Kopecky and Scherlis 2008). When it is understood in terms of political appointments to positions within state institutions, as it is done here, patronage may fulfil three different sets of functions.

First, public jobs as a prominent material incentive for political participation among party supporters has been the form of patronage on which scholars of party organization have mainly focused. Accordingly, patronage works as a reward by distributing jobs at the bottom of the state in order to establish loyal electoral support and sustain the networks of partisan activists on the ground. It is in this sense that patronage can be seen as a particularistic exchange aimed at establishing modern clienteles (Piattoni 2001).

Second, appointments can be used to support the political control of administrative bodies, acting as a supplementary strategy of executive leadership (Lewis 2008). When viewed as 
the practice of appointing networks of trusted professionals to positions of authority in the state institutions, patronage can be considered as a governmental resource (Ware 1996). This argument assumes that governing parties as principals face a natural problem of controlling their bureaucratic agents when it comes to policy design, implementation and coordination. In line with this argument, patronage is expected to help political principals to steer public bureaucracies so as to reach policy outputs closer to their own preferences (Dahlstrom 2011).

However, the precise interpretation of what political appointments of professionals at the top of state institutions entail is not as clear-cut (Kopecky and Spirova 2011). Political appointments in higher level positions may not be understood in the sense of implementing the policies formulated by the government, but rather taking over state institutions and manipulating them to the advantage of political actors. More specifically, patronage at the top of state institutions may serve a third goal, that is exploitation as a distinct state capture strategy that occurs when incumbents extract state resources without rent distribution to supporters (Grzymala-Busse 2008). Exploitation does not imply those forms of mass mobilization typical of "bureaucratic clientelism" as an extractive strategy that consists of the systematic infiltration of the state machine by party devotees and the allocation of favours through it so as to secure power and maintain the party's electoral base (Lyrintzis 1984). On the contrary, in the context of exploitative regimes incumbents do not take advantage of the control of top rank position in order to develop large-scale particularistic exchanges, but they focus on the extraction of those state assets needed to fuel parties as competing arrangements of personalities rather than mass organizations.

In addressing the issue of the role of party patronage in contemporary democracies, Kopecky and Scherlis (2008) have argued that political appointments are increasingly less 
aimed to reward party loyalty as they are the means to enhance the governmental control over state agencies. According to Kopecky and Scherlis, recent organizational transformations among the European political parties suggest that they have become public utilities which tend to present themselves to the voters as successful governors and competent office-holders (Katz and Mair 2009). It is therefore not surprising that contemporary party organizations dominated by the party in public office are interested in appointing networks of professionals to reinforce their grip over the process of policy implementation and their own strength as agencies of government. The stimulus towards the predominance of patronage as governmental control has also been enhanced by the fragmentation of contemporary systems of governance. As governance becomes more dispersed, parties face an intensified need to rely on patronage as a critical linkage mechanism facilitating policy coordination within an internally differentiated government apparatus (Bolleyer 2011, Flinders 2012).

While Kopecky and Scherlis contend that the increasingly standardized conditions in which parties compete call for the convergence of patronage patterns, the classic account advanced by Shefter (1977) highlights the cross-national variation in the use of patronage determined by the temporal order of bureaucratization and the emergence of party competition. By emphasizing the path dependent effects on patterns of patronage triggered by the sequencing of bureaucratization and democratization, Shefter adopted the logic of explanation typical of historical institutionalist analyses of political processes (Pierson 2004, Thelen 1999). A more recent research strand has refined the Shefterian account by invoking the role of the deficiencies in party system institutionalization as the mechanism that reproduce patterns of patronage as reward in those settings where party competition takes place prior to the consolidation of bureaucratic autonomy. Analyzing postcommunist 
democracies, O'Dwyer (2006) has identified the fragmentation and instability of the party system as the crucial precondition for the "runaway state building", that is the patronageled expansion of public sector personnel. O'Dwyer suggests that one mechanism for the reproduction of the legacy of the past may be the tempo with which party change occurs. When the pacing of transformation is rapid, as it happens in underinstitutionalized party system, the general uncertainty shortens the time horizons of incumbents, encouraging them to substitute patronage for programmatic support in building party organizations.

I build on these distinctions and hypotheses concerning the role of patronage in contemporary democracies to shed light on patterns of patronage in Italy. The peculiar historical trajectory of the party system makes Italy an interesting case for testing the alternative hypothetical scenarios of patronage politics suggested by literature. As mentioned above, the inauguration of the democratic regime in the lack of a consolidated autonomous bureaucracy left Italian state structures at the disposal of incumbents who had the chance to resort to patterns of bureaucratic clientelism as a viable strategy for political mobilization. After decades of systematic party colonization of the state, however, the dramatic crisis of the early 1992 - characterized by the exceptional breakdown of the party system - revealed how the increased rigidity and accumulated contradictions that arise from long-term processes of institutional reproduction of bureaucratic clientelism can build up to a tipping point leading to abrupt collapse of party organizations (Warner 1997).

Drawing on the historical institutional approach, there are three alternative implications of the early 1990s crisis for practices of patronage in Italy. In the first hypothetical scenario, the crisis may reveal the critical influence of parties' environment to the point of triggering a "critical juncture" in patronage politics, thus enabling the abrupt shift from bureaucratic clientelism to patronage as a governmental resource. In this scenario, as hypothesized by 
Kopecky and Scherlis, the influence of the environment would thus outweigh the relevance of the institutional legacies of a weak state, eventually disrupting path-dependent patterns of patronage. In the second scenario, as hypothesized by O'Dwyer, the crisis would not imply any shift in patterns of patronage as poorly consolidated state structures inherited from the old partitocrazia would lack the autonomy to resist capture in the context of a new party system characterized by the underinstituzionalization of party organizations. In the third scenario, the crisis would induce an incremental change from clientelism to exploitation as distinct patterns of state capture. If this were to be the case, the transformation of patronage practices would be best highlighted in terms of the catalogue of modes of incremental change introduced by Streeck and Thelen (2005) to nuance the original historical institutionalist dichotomy between path-dependent stability and abrupt radical change. More specifically, the shift from clientelism to exploitation can be regarded as a case of "conversion" as the inherited weakness of state structures has been redirected from the old mass mobilization to the new reproduction of party elites.

On the one hand, the third scenario can be distinguished from the first one on the basis of the sequencing effect which is related to the inherited low professionalism of bureaucracy as an incentive for new party elites to develop state capture strategies. On the other hand, the third scenario differs from the second one as it reflects the relevance of the timing effect which is related to contextual features typical of the postmodern age in which new parties emerged in Italy. The timing effects is that the perpetuation of the old patterns of patronage is unlikely in a different temporal context of party formation marked by the absence of dense party organization and expanding public employment as conditions conducive to bureaucratic clientelism (Grzymala-Busse 2008). When the European pressures for reforming and streamlining public administration reduce patronage opportunities on the 
supply side and the lack of dense organizational networks makes difficult to sustain credible rent delivery and monitoring channels, incumbents are more likely to extract resources from a weak state for themselves.

In order to test these alternative scenarios in the subsequent empirical part of this paper, I use a dataset produced within a cross-national research project with the help of a new method which is presented in the next section.

\section{METHOD}

The data that I use to explore patterns of patronage in Italy comes from an expert survey conducted in 15 old and new democracies which represent different types of institutional legacies. Most importantly, the countries under investigation also differ in terms of periods of party formation and patterns of political competition. Drawing on this cross-national survey, thus, the scenarios outlined above can be tested against a wider comparison that allows to appreciate the relative position of Italy in relation to the European counterparts.

The selection of expert interviews as the main source of the information has been determined by the amorphousness, latency, and elusiveness of dyadic relationships which make the identification of patronage within modern state institutions a very complex affair (Landé 1983). Experts interviews may be an appropriate source in the field of comparative politics (Rathburn 2008), providing a wealth of insider information that constitute the only real research strategy when studying a covert phenomenon such as patronage (Müller 2000). Furthermore, challenges for the validity of research posed by the use of soft data have been addressed in several ways. First, the experts hail from a variety of backgrounds: from politicians, senior civil servants and top managers, to academics. Second, surveys were 
conducted face-to-face by country teams who validated information gathered through interviews with alternative primary and secondary sources. Last, the interviews had both open- and closed-ended so as to add thicker insights to the categorical assessment.

Interviews were conducted in 2008-2009 with experts knowledgeable about political appointments in nine different policy sectors (media, finance, economy, judiciary, foreign affairs, culture and education, military and police, healthcare, regional and local government). For each policy sector five respondents were selected using the expertise of the country teams complemented by the use of the snowball technique. To obtain more detailed information, for each of those nine policy sectors a number of administrative bodies were selected and grouped into three different types of institutions: ministries, nondepartmental agencies and commissions, and executing institutions involved in service production and provision, such as state-owned companies, hospitals, and schools. In other words, the research strategy is intended to account for the possible variances in levels and rationale of patronage across different policy sectors and institutional types.

Data were gathered and aggregated by following the steps proposed by Kopecky et al. (2008). First, experts were asked about the scope of political appointments, that is the level of politicization of state institutions along two dimensions: the range of patronage, that is how many state institutions parties are capable to reach; the depth of patronage, that is how many organizational levels of state institutions are affected by politicization, from the top managerial level to the bottom technical and service personnel. On the basis of all the answers to these two questions, the median score was calculated for range and depth for every policy sector and institutional type. Second, questions dealing with further aspects of patronage such as the profile of the actual people who get appointed and the motivations behind their nomination within each policy sector were open-ended and reported with 
simpler statistics at a later stage. Finally, open-ended questions dealing with the mechanisms through which parties select people to be appointed and the evolution of patterns of patronage over time were only analyzed qualitatively.

EMPIRICAL ANALYSIS

Levels of Patronage

I first try to investigate whether the levels of patronage in Italy are higher than in the rest of countries included in the cross-national research project. For this purpose I report in Figure 1 the values of the Index of Patronage which is an aggregate measure combining the survey answers on range and depth of political appointments.

[FIGURE 1 ABOUT HERE]

Italy displays one of the highest levels of patronage in comparative perspective with an index of 0.47 well above the mean for the sample of countries. This value locates Italy in the higher end of the sample which includes also Austria and Greece, long considered patronage countries in Europe (Muller 2000). In the face of the data, the Shefter's hypothesis on the association of weak stateness and politicization of the state is therefore confirmed since democracies in Northern Europe, where bureaucratization preceded democratization, display quite low party appointments within the state institutions. Interestingly, however, the current levels of patronage in Italy are lower than in a case of bureaucratic clientelism such as Greece with a value of 0.62 which means that parties appoint in most institutions at all levels of the administration. The lower index in Italy is owing to the variation across 
policy sectors and institutional types that emerges clearly if we look at the disaggregated data reported in Table 1.

[TABLE 1 HERE]

The variation among state institutions along substantive lines suggests that particular constrains make some policy sectors partially insulated from politicization. In the case of sectors such as Military and Police, Foreign Affairs and Justice, parties are constrained by the presence of professional corps which privilege bureaucratic criteria in career paths. Instead, the limited patronage practices in the executive domain of Culture and Education are arguably attributable to the complexity of formal recruitment procedures that prevent higher actual levels of patronage within schools. Experts pointed also to the high professional demands on the job in a sector such as Finance and Economy which iare highly exposed to international financial institutions. In contrast, the sector which is the most patronage-ridden is that of Media because of the high policy salience for parties coupled with the absence of particular constraints.

Differentiation of patronage levels across state institutions can be better identified by looking at the table 2 which shows data on the range and depth of political appointments at the central level of government.

[TABLE 2 ABOUT HERE]

The high values for the range of patronage across organizational types indicate that political appointments are pervasive in central as just a very few state institutions are immune from 
politicization. As far as depth is concerned, data show that parties are very likely to reach into the middle levels of the ministerial bureaucracy. The values for depth within the other two organizational types reveal that patronage declines as we move away from the ministries, a pattern that contrasts with the previous partitocratic regime characterized by the sweeping party colonization of disaggregated bodies (Golden 2003). The lower levels of depth in the non-ministerial settings reflect patterns of political appointment that are limited to the highest positions in a large number of policy sectors under investigation. According to the interviewees, these patterns of lower depth highlight the impact of processes of bureaucratic reform that have been initiated since the early 1990s under European pressure for reduction of public spending and state assets privatization. The process of European integration has thus reduced opportunities for patronage at the bottom acting as an external source of constraints for parties whose patronage practices in disaggregated state bodies had to adapt to the culture of macroeconomic stability and market liberalization institutionalized by membership of the EMU. At the central level, however, party elites have not only been constrained by European pressures but they also turned out to be less interested in patronage as a resource for building party organizations and electoral clienteles. Given the instability of party loyalties, party rulers are discouraged from entering into distributive contracts with their supporters since the parties lack the capacity to develop the channels of monitoring and delivery. In a context marked also by the relevance of national media campaigns, thus, offering selective benefits to supporters is both inefficient and implausible as hypothesized by Grzymala-Busse (2008).

At the subnational level, however, patronage proliferates as highlighted by the median scores of range (1.0) and depth (0.89) calculated on the basis of experts' answers. Parties can reach all the levels of the subnational administration where Europe exerts a less intense 
pressure for bureaucratic reform and local elites have taken advantage of the opportunities offered by the corporatization of disaggregated bodies to fill with party appointees organizations created from scratch. Data show that the scope of particularistic change is wider at the local level, especially in Southern Italy, and it encompasses also forms of patronage at the bottom as an electoral strategy. As also highlighted by the following empirical section, local patronage is managed by notables since contemporary parties are marked by the absence of a well-structured organization beyond the personal circles gathered around public office holders. This means that notables are not concerned with building a large and permanent structure as they are with reinforcing their personal clienteles through the distribution of appointments as selective benefits. While the sharp decline of patronage at the bottom in central state institutions has implied the demise of the party-directed clientelism that characterized the previous regime, clientelism has therefore survived at the local level by assuming the traditional forms of the clientelism of notables aimed at maintaining personal committees rather than mass organizations.

The Logic and Mechanics of Patronage

As reported in Table 3, while professional qualification is a required appointee characteristic in Italy as well as in European democracies, political allegiance is clearly less relevant in Italy than in rest of the sample.

[TABLE 3 ABOUT HERE] 
Interviewees underlined the low party institutionalization as the determinant of such a low relevance of political links in comparative perspective. In fact, the fluidity of party loyalties proved inimical to the development of partisan relationships of trust between elites and appointees as ever-changing political affiliations could not constitute an important clue regarding appointees' preferences. In contrast, in the rest of European democracies characterized by the stability of party loyalties, partisanship provides party elites with the assurance that they will obtain responsiveness from appointees.

The low relevance of political links as a condition for appointment reflects the lack of involvement of party organizations in the recruitment process. Since competent and trustworthy candidates cannot come from the ranks of unstable parties, the leaders placed at the intersection between cabinet and party executive have become the dominant actor in the selection process. It comes thus at no surprise that the decline of parties organizations as channel for elites' recruitment has increased the relevance of personal linkages in the appointment process. Given the lack of bonds of trust between political and managerial elites built by the party organizations, party leaders rely on their personal networks of affinities to penetrate state institutions. Personalization of the Italian patronage practices contrasts with patterns exhibited by those parties that emerged as mass organizations in old democracies where the elite in government are primarily responsible for the allocation of jobs but they are not free from proposal and scrutiny over candidates from party organizations in making the appointments.

In Italy personalized processes of recruitment generally take place in two phases: first, party leaders build their personal entourages made of loyal experts from the policy sector of 
interest; then, it is the single experts of that entourage to explore their own personal networks in search of trustworthy managers to whom a position may be given. Consequently, policy sectors are managed by a cluster of loosely connected networks, with different backgrounds unrelated to party organizations, but which offer responsiveness to party leaders. Personalization of appointment processes dominated by the party elites holding government offices have also brought noticeable changes to the relationship of local notables vis-à-vis national party leaders by reinforcing trends toward a "stratarchical" (Carty 2004) configuration of Italian parties as party governors at all levels of government enjoy mutual autonomy in managing political appointments in order to satisfy their personal networks of support.

Viewed from the perspective of recruitment processes, patronage therefore performs the role of the glue that holds together a collection of elite networks recruited from outside the party boundaries by mutually autonomous leaders. Not surprisingly, as shown by Table 3, party leaders are concerned about appointing at top state positions a network of experts characterized by strictly personal loyalty in order to control the functioning of administrative institutions.

\section{[TABLE 4 ABOUT HERE]}

The prevalence of control over reward as motivations behind patronage reveal that O'Dwyer's argument about runaway state building in new democracies is incomplete. While the O'Dwyer's understanding of patronage suggests that political appointments are motivated by the need to build and maintain party organizations by rewarding their members and activists, the findings on the motivation of patronage - complemented with 
the analysis of levels and mechanisms of patronage reported above - show that party elites are primarily interested in patronage as a control device not only in Italy but also in the other new democracies of the sample which share the legacy of weakly consolidated bureaucracies. As highlighted by the extremely high levels of patronage, Greece is the only case which exhibits patterns of patronage as proposed by O'Dwyer. However, runaway state building has been prompted by the strong governance of well-institutionalized party organizations sustained by polarization and statism as distinctive features of the Greek system (Pappas 2009), rather than by the weak governance of under-institutionalized parties as hypothesized by O'Dwyer. Conversely, control of state institutions is the driving force of patronage in those democracies marked by the lower polarization of party competition, such as Spain and Portugal (Morlino 1998), or by the formation of parties in a context of popular disaffection towards parties and ever-increasing European pressure for state and economy reform, such as Italy and post-communist democracies (Kopecky and Spirova 2011, 918).

Thus, pace O'Dwyer, Italian party elites manage appointments for controlling public institutions in order to cement their own personal linkages with the State rather than building organizational linkages with society. Patronage as control regulates the distribution of top state positions to loyal experts which is aimed at capturing state resources. Patterns of state exploitation emerge if we consider the interpretation of professional qualification advanced by the interviewees who highlighted that often this appointee requisite means just a minimum level of expertise and proficiency for the job. This implies that parties are not primarily interested in appointing the most qualified people so as to enhance their state management capacity and reputation as it happens in Northern democracies where party elites face autonomous bureaucracies. The trend towards state exploitation is particularly 
underlined by the interpretations of control provided by the interviewees who emphasized the extraction of state resources as the dominant use of patronage. In addition, state capture mostly sustains strategies directed at consolidating incumbents' personal networks of support rather than clientelistic strategies of rent distribution. As highlighted by the interviewees, the quickly unfolding political change in Italy has inhibited the formation of a coalition for bureaucratic autonomy which represents the most relevant constraint on state capture in the influential analysis of Shefter. Since political elites had little time for aligning and mobilizing such a coalition, they relied on the inherited particularistic circles entrenched within weak state structures to insure themselves during the restructuring of the party system. The rapid tempo of party transformations has therefore privileged the small elite cohorts who held executive positions and were capable of exploiting the state so as to keep party organizations subordinated to their personal power.

Notwithstanding the prevalence of control, reward is still a relevant motivation behind appointments because parties need to distribute marginal positions at the middle and lower levels so as to maintain a minimum level of activism on the ground. In particular, local notables have taken advantage of the wider scope of patronage within subnational institutions, to reinforce their personal committees as the only structure on the ground providing capacity for political mobilization to national leaders.

\section{DISCUSSION AND CONCLUSIONS}

This article examined what happened to patterns of patronage, conceptualized as political appointments within administrative bodies, in Italy after the abrupt party system breakdown of the early 1990s. It sought to assess whether contemporary practices of patronage have been influenced by the legacy of weakly consolidated bureaucratic 
structures or whether they have radically departed from the patterns of bureaucratic clientelism typical of the old partitocrazia.

Empirically, the analysis provides support for the third hypothetical scenario outlined in the research framework as current practices of patronage support exploitation-oriented forms of political control over state agencies aimed at capturing weak administrative structures for the convenience of the newly governing elites. With regard to the debate on change in Italian politics after the early 1990s crisis, the findings are therefore consistent with the research argument that identified patterns of limited change characterized by the influence of the institutional legacies which prevented a veritable transition to a new institutional order (Bull and Rhodes 2007). The findings also specify the dynamics that have driven incremental change forward by evoking the rapid tempo of political change in Italy as the key determinant of the gradual "conversion" (Streeck and Thelen 2005) from bureaucratic clientelism to state exploitation. In fact, the rapid pacing of change in a floating party system deprived of stable loyalties encouraged party elites to maintain the patterns of particularistic control over weak bureaucracies inherited from the old regime as the readily accessible tool to establish their authority over political processes in the shortest term.

Thus, state capture has been perpetuated by the interaction of the sequencing effect highlighted by Shefter in the traditional account of patronage politics with the tempo effect underlined by O'Dwyer in the recent analysis of the intertwining between party building and state building across post-communist democracies. However, this interaction has not generated the runaway state-building as hypothesized by O'Dwyer whose account overlooked the timing effect on patterns of patronage exerted by the broader societal and international context in which the Italian transition occurred. On the contrary, the findings pointed to the relevance of public spending reduction under pressures from EMU and 
popular disaffection towards as contextual features which constrained the parties' ability to access state resources and channel them through credible exchange contracts enforced by organizational networks. While Shefter pointed to the relevance of the domestic coalitions for bureaucratic autonomy as the major constraint for patronage, the findings reveal that international organizations such as the EU have been a powerful source of bureaucratic reform since contemporary democracies tend to be under far stronger external scrutiny than democracies analysed by Shefter (Kopecky and Spirova 2011). Under these international pressures for reform, the old bureaucratic clientelism could not thrive and party elites redirected the inherited politicization of weak bureaucracies to state exploitation.

By explicitly specifying how changes in patterns of patronage in Italy have been shaped by inherited institutional arrangements (sequencing effect), the pacing of party system restructuring (tempo effect), and the context of party formation (timing effect), this article reveals the potential for researchers of an historical institutionalist approach that is especially sensitive to the role of temporality in politics. Specifically, it calls our attention to better address the constituent aspects of temporality and how they constitute and differentiate the unfolding of historical trajectories underlying political processes (GrzymalaBusse 2011).

The analysis of patterns of patronage grounded in temporality has also major implications for our understanding of party development in contemporary democracies as it warns us against the use of existing party models affected by the 'transformation bias' that has been already highlighted by recent research on party politics in new democracies (Biezen 2005; Webb and White 2007). According to this strand of research, the cartel party model reflecting the transformation of parties which have formed as strong movements of society 
in early democratizing Western Europe cannot grasp the organizational reality of parties in new democracies which have followed a different path of development as they emerged in a different period and a different institutional context. Since the same distinction between these two paths of development holds for the new Italian parties emerging after the early 1990s crisis of the democratic regime centered on the party colonization of a weak state (Morlino 1998), it is therefore not surprising that the empirical analysis pointed out patterns of patronage that differ from their contemporary counterparts in the older democracies with respect to the balance of power between the governing elites and the party as collective organizations. In fact, the personalized and particularistic nature of political appointments in Italy revealed that political personalities make use of patronage for reinforcing their own power bases, rather than acting as the leaders of collective agencies to entrench organizational networks within the state machinery.

Further, the congenital differences between patronage functions according to when parties emerged lead us to ask about the implications of patronage for party institutionalization in late party systems (Randall and Svasand 2002). The first implication is that the sequence effect on institutionalization in late party systems cannot be related just to the emergence of television as a major campaign vehicle before parties are well entrenched (Mainwaring and Zoco 2007). The findings support the claim that historical legacies are another crucial variable affecting levels of party institutionalization (Hicken and Martinez-Kuonta 2011). More specifically, the analysis highlighted that for a country such as Italy the "shadows from the past" are rooted in the weakness of state bureaucracies as a contextual feature that makes state capture available to help party elites in building and maintaining their personalized networks of support during quickly unfolding party system restructuring processes (Perkins 1996). This finding concerns the impact of the state of party politics on 
the quality of democratic governance which is not linear as revealed by previous research (Croissant and Volkel 2012). In fact, this research pointed out the role of low professionalization of state bureaucracies as an intervening factor which greatly intensifies the shortcomings of the party system.

Further, the findings reveal the complementarity between the institutional effect of party system configuration and the temporality effects of party formation in searching for an explanation of the opportunity costs of patronage for party institutionalization. Warner (1997) suggested that patronage has determined the abrupt de-institutionalization of the old Italian parties which emerged in a polarized competitive system by locking-in their mass organizations through patterns of bureaucratic clientelism to the point of making them incapable to adapt to environmental changes. The analysis reported here instead highlights that patronage has locked-in the under-institutionalization of new Italian parties emerged in a fluid competitive system by sustaining the state exploitation from newly governing elites, thus preventing the consolidation of that kind of organizational cohesion displayed by institutionalized parties in consolidated democracies (Bolleyer 2011).

Thus, patronage has proved to be a resilient barrier that contributed to obstructing the coherent consolidation of a new democratic regime in Italy. The empirical analysis therefore highlights the changing role of patronage for democratic consolidation in Italy. Morlino (1998) stressed the role of patronage as an anchor facilitating consolidation in the face of the gap in legitimacy resulting from the pattern of exclusive consolidation of post-war Italy but in the recent context - marked by the disappearance of the legitimacy gap - practices of patronage increase the inefficiency of the administrative system, eventually losing any integrative character by heightening the widespread dissatisfaction towards unresponsive institutions. 
However, by highlighting the role of temporality in a process of democratic crisis and transition marked by intense party system restructuring, this article suggests the need for more work on the role of institutional legacies in the experience of party institutionalization and democratic consolidation. In fact, empirical evidence that supports the arguments advanced here remains limited to the Italian case and more comparative research needs to be done on the issues of party institutionalization and democratic consolidation. 


\section{REFERENCES}

Baldini, Gianfranco (2011) 'The Different Trajectories of Italian Electoral Reforms' West European Politics 34: 644-663.

Biezen, Ingrid van (2004) 'Political Parties as Public Utilities’ Party Politics 10: 701-722.

Biezen, Ingrid van (2005) 'On the theory and practice of party formation and adaptation in new democracies" European Journal of Political Research 44: 147-174.

Biezen, Ingrid van (2008) 'State Intervention in Party Politics: The Public Funding and Regulation of Political Parties' European Review 16: 337-353.

Biezen, Ingrid van and Petr Kopecky (2007) 'The State and the Parties' Party Politics 13: 235254.

Bolleyer, Nicole (2011) 'The Influence of Political Parties on Policy Coordination' Governance: 469-494.

Bosco, Anna and Leonardo Morlino (2006) 'What Changes in South European Parties? A Comparative Introduction' South European Society \& Politics 11: 331-358.

Bull, Martin and Martin Rhodes (2007) 'Introduction - Italy: A Contested Polity' West European Politics 30: 657-669.

Carty, R. Kenneth (2004) 'Parties as Franchise Systems: The Stratarchical Organizational Imperative' Party Politics 10: 5-24.

Cassese, S. (1993) 'Hypotheses on the Italian Administrative System” West European Politics 16: 316-328.

Citroni, Giulio (2009) 'Governo Spa: Pubblico e privato nelle società partecipate degli enti locali' Rivista Italiana di Scienza Politica 39: 87-111. 
Croissant, Aurel and Philip Volkel (2012) 'Party System Types and Party System Institutionalization: Comparing New Democracies in East and Southeast Asia' Party Politics 18: $235-265$.

Dahlstrom, Carl (2011) 'Who Takes the Hit? Ministerial Advisers and the Distribution of Welfare Cuts' Journal of European Public Policy 18: 294-310.

Dyson, Kenneth and Kevin Featherstone (1996) 'Italy and the EMU as the "Vincolo Esterno": Empowering the Technocrats, Transforming the State' South European Society \& Politics 1: 272-299.

Flinders, Matthew (2012) 'Governance and Patronage', in David Levi-Faur (ed) The Oxford Handbook of Governance, ed D. Levi-Faur, Forthcoming. Oxford: Oxford University Press.

Golden, Miriam (2003) 'Electoral Connections: The Effects of the Personal Vote on Political Patronage, Bureaucracy and Legislation in Postwar Italy' British Journal of Political Science 33: $189-212$.

Grzymala-Busse, Anna (2008) 'Beyond Clientelism: Incumbent State Capture and State Formation' Comparative Political Studies 41: 638-673.

Grzymala-Busse, Anna (2011) 'Time Will Tell? Temporality and the Analysis of Causal Mechanisms and Processes' Comparative Political Studies 11: 1267-1297.

Gunther, Richard and Larry Diamond (2003) 'Species of Political Parties: A New Typology' Party Politics 9: 167-199.

Gunther, R., N.P. Diamandouros and D. Sotiropoulos (eds.) (2006) Democracy and the State in the New Southern Europe. Oxford: Oxford University Press.

Hicken, Allen (2011) 'Clientelism' Annual Review of Political Science 14: 289-310.

Hicken, Allen and Eric Martinez Kuhonta (2011) 'Shadows from the Past: Party System Institutionalization in Asia' Comparative Political Studies 44: 572-597. 
Huntington, S. (1968) Political Order in Changing Societies. New Haven, CT: Yale University Press.

Ignazi, Piero, Luciano Bardi and Oreste Massari (2010) 'Party Organisational Change in Italy (1991-2006)’ Modern Italy 15: 197-216.

Ignazi, Piero and Colette Ysmal (1998) The Organization of Political Parties in Southern Europe. Westport CT: Praeger

Immergut, Ellen and Karen Anderson (2008) 'Historical Institutionalism and West European Politics' West European Politics 31: 345-369.

Katz, Richard and Peter Mair (2009) 'The Cartel Thesis: A Restatement' Perspectives on Politics 7: 753-766.

Kitschelt, Herbert and Steven Wilkinson (2007) 'Citizen-politician Linkages: An Introduction', in Herbert Kitschelt and Steven Wilkinson (eds) Patrons, Clients, or Policies? Patterns of Democratic Accountability and Political Competition, pp. 1-50. Cambridge: Cambridge University Press.

Kopecky, Petr and Gerardo Scherlis (2008) 'Party Patronage in Contemporary Europe' European Review 16: 355-371.

Kopecky, Petr, Gerardo Scherlis and Maria Spirova (2008) 'Conceptualizing and Measuring Party Patronage' Mexico City: IPSA Committee on Concepts \& Methods.

Kopecky, Petr and Maria Spirova (2011) 'Jobs for the Boys? Patterns of Party Patronage in Post-Communist Europe' West European Politics 34: 897-921.

Landé, Carl (1983) 'Political Clientelism in Political Studies' International Political Science Review 4: 435-452.

Levitsky, S. (1998) 'Institutionalization and Peronism' Party Politics 4: 77-92. 
Lewis, David E. (2008) The Politics of Presidential Appointments. Princeton NJ: Princeton University Press.

Lyrintzis, Christos (1984) 'Political Parties in the Post-Junta Greece: A Case of Bureaucratic Clientelism?' West European Politics 7: 99-118.

Mainwaring, Scott and Mariano Torcal (2006) 'Party System Institutionalization and Party System Theory after the Third Wave of Democratization' in Richard Katz and William Crotty (eds.) Handbook of Party Politics, pp. 204-217. London: Sage.

Mainwaring, Scott and Edurne Zoco (2007) 'Political Sequences and the Stabilization of Interparty Competition' Party Politics 13: 155-178.

Morlino, Leonardo (1998) Democracies between Consolidation and Crisis. Oxford University: Oxford University Press.

Müller, Wolfgang C. (2000) 'Patronage by National Governments', in Jean Blondel and Maurizio Cotta (eds) The Nature of Party Government, pp. 141-160. London: Palgrave.

O'Dwyer, Conor (2006) Runaway State Building: Patronage Politics and Democratic Development. Baltimore MD: Johns Hopkins University Press.

Panebianco, Angelo (1988) Political Parties: Organization and Power. Cambridge: Cambridge University Press.

Pappas, Takis (2009) 'Patrons Against Partisans: The Politics of Patronage in Mass Ideological Parties' Party Politics 15: 315-334.

Pasquino, Gianfranco (1997) ‘No Longer a Party State? Institutions, Power and the Problems of Italian Reform' West European Politics 20: 34-53.

Perkins, Doug (1996) 'Structure and Choice: The Role of Organizations, Patronage and the Media in Party Formation' Party Politics 2: 355-375. 
Piattoni, Simona (2001) 'Clientelism in Historical and Comparative Perspective', in Simona Piattoni (ed) Clientelism, Interests, and Democratic Representation, pp. 1-29. Cambridge: Cambridge University Press.

Pierson, Paul (2004) Politics in Time. Princeton NJ: Princeton University Press.

Randall, Vicky and Lars Svasand (2002) 'Party Institutionalization in New Democracies' Party Politics 8: 5-29.

Rathburn, Brian C. (2008) 'Interviewing and Qualitative Field Methods', in Janet M. BoxSteffensmeier, Henry E. Brady and David Collier (eds) The Oxford Handbook of Political Methodology, pp. 685-700. Oxford: Oxford University Press.

Sartori, Giovanni (1976) Parties and Party Systems. Cambridge: Cambridge University Press.

Selznick, P. (1957) Leadership in Administration. New York: Harper \& Row.

Shefter, Martin (1977) 'Party and Patronage: Germany, England, and Italy' Politics \& Society 7: 403-451.

Sotiropoulos, Dimitri (2004) 'Southern European Bureaucracies in Comparative Perspective' West European Politics 27: 405-422.

Streeck, Wolfgang and Kathleen Thelen (2005) 'Introduction: Institutional Change in Advanced Political Economies', in Wolfgang Streeck and Kathleen Thelen (eds) Institutional Change in Advanced Political Economies, pp. 1-39. Oxford: Oxford University Press.

Thelen, Kathleen (1999) 'Historical Institutionalism in Comparative Politics' Annual Review of Political Science 2: 369-404.

Ware, Alan (1996) Political Parties and Party Systems. Oxford: Oxford University Press. Warner, Carolyn M. (1997) 'Political Parties and the Opportunity Cost of Patronage' Party Politics 3: 533-548. 
Webb, Paul and Stephen White (2007) 'Political Parties in New Democracies: Trajectories of Development and Implications for Democracy', in Paul Webb and Stephen White (eds) Party Politics in New Democracies, pp. 347-376. Oxford: Oxford University Press. 
FIGURE 1. EUROPEAN DEMOCRACIES, INDEX OF PATRONAGE

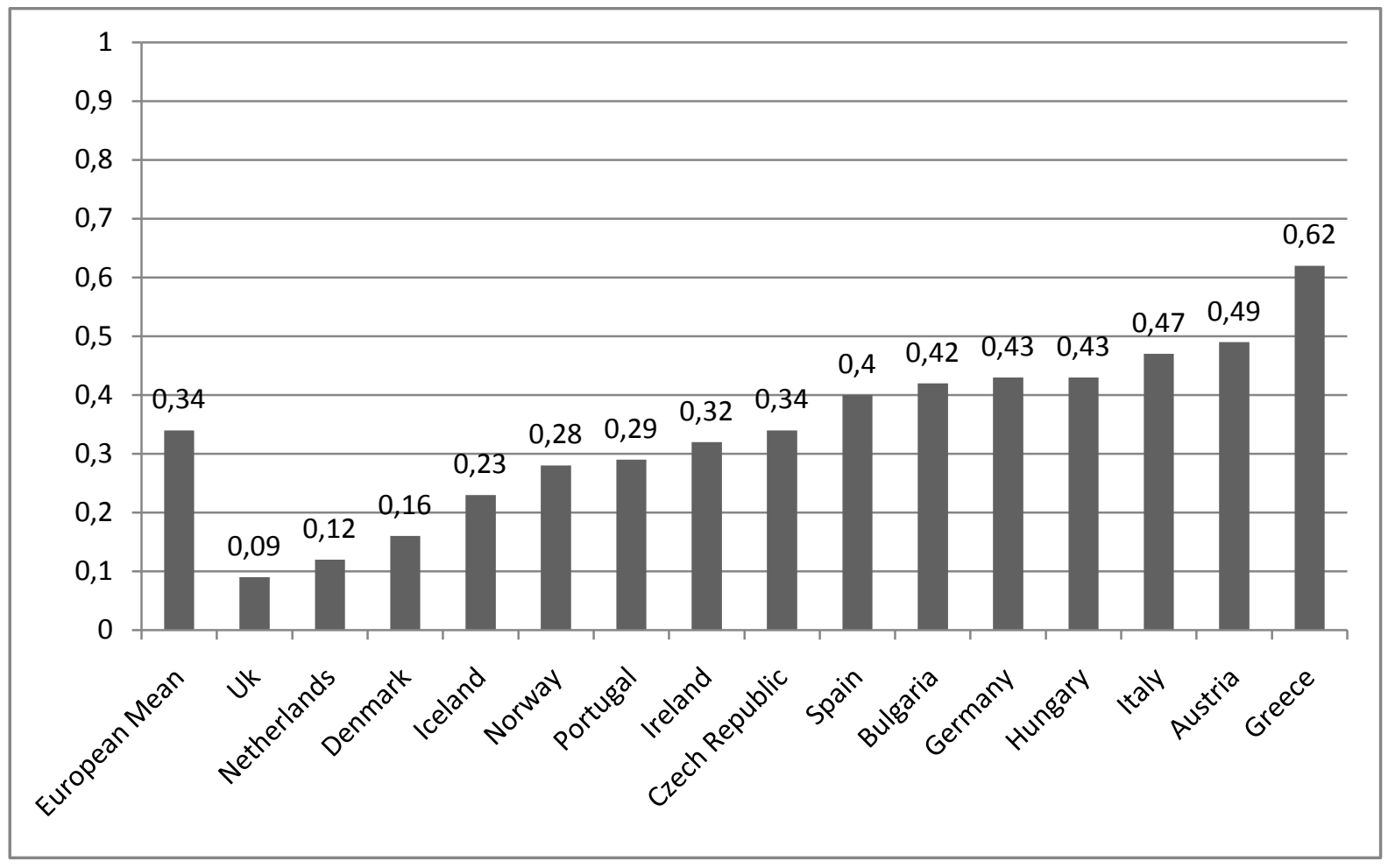

TABLE 1. Italy, Index of Patronage: Policy Sectors and Institutional Types

\begin{tabular}{|c|c|c|c|c|}
\hline Policy Sector & Ministries & $\begin{array}{c}\text { NonDepartmental } \\
\text { Bodies }\end{array}$ & $\begin{array}{c}\text { Executing } \\
\text { Institutions }\end{array}$ & $\begin{array}{c}\text { Policy Area } \\
\text { Total }\end{array}$ \\
\hline ECONOMY & 0,67 & 0,33 & 0,33 & $\mathbf{0 , 4 4}$ \\
\hline FINANCE & 0,67 & 0,22 & 0,22 & $\mathbf{0 , 3 7}$ \\
\hline JUDICIARY & 0,67 & 0,33 & 0,11 & $\mathbf{0 , 3 7}$ \\
\hline MEDIA & 0,67 & 0,33 & 1,00 & $\mathbf{0 , 6 7}$ \\
\hline MILITARY \& POLICE & 0,33 & 0,33 & 0,11 & $\mathbf{0 , 2 6}$ \\
\hline HEALTHCARE & 0,67 & 0,33 & 0,33 & $\mathbf{0 , 4 4}$ \\
\hline CULTURE \& EDUCATION & 0,67 & 0,33 & 0,22 & $\mathbf{0 , 4 1}$ \\
\hline FOREIGN SERVICES & 0,67 & NA & 0,11 & $\mathbf{0 , 3 9}$ \\
\hline SUBNATIONAL ADMINISTRATION & 0,67 & 1,00 & 1,00 & $\mathbf{0 , 8 9}$ \\
\hline Total & $\mathbf{0 , 6 3}$ & $\mathbf{0 , 4 0}$ & $\mathbf{0 , 3 8}$ & $\mathbf{0 , 4 7}$ \\
\hline
\end{tabular}

TABLE 2. Italy, Range and Depth of Patronage: Institutional Types

\begin{tabular}{ccccc}
\hline & Ministries & $\begin{array}{c}\text { NonDepartmental } \\
\text { Public Bodies }\end{array}$ & $\begin{array}{c}\text { Executing } \\
\text { Agencies }\end{array}$ & Total \\
\hline RANGE & 0.94 & 0.95 & 0.67 & 0.85 \\
DEPTH & 0.67 & 0.33 & 0.42 & 0.48 \\
\hline
\end{tabular}


TABLE 3. European Democracies: Qualification of Appointees (\%)

\begin{tabular}{lcccc}
\hline Country & Professionalism & $\begin{array}{c}\text { Political } \\
\text { Link }\end{array}$ & $\begin{array}{c}\text { Personal } \\
\text { Allegiance }\end{array}$ & Other \\
\hline GREECE & 98 & 100 & 64 & 33 \\
AUSTRIA & 96 & 100 & 89 & 00 \\
ITALY & 93 & 22 & 84 & 00 \\
GERMANY & 95 & 93 & 73 & 12 \\
HUNGARY & 75 & 93 & 43 & 00 \\
BULGARIA & 59 & 90 & 58 & 15 \\
SPAIN & 93 & 82 & 47 & 00 \\
CZECH REP. & 80 & 88 & 63 & 00 \\
IRELAND & 88 & 73 & 71 & 33 \\
PORTUGAL & 85 & 77 & 78 & 00 \\
NORWAY & 100 & 52 & 24 & 69 \\
ICELAND & 80 & 59 & 21 & 05 \\
DENMARK & 100 & 24 & 00 & 63 \\
NETHERLANDS & 96 & 64 & 38 & 00 \\
UK & 84 & 24 & 16 & 27 \\
EUROPEAN MEAN & $\mathbf{8 8 , 1 0}$ & $\mathbf{6 9 , 4 0}$ & $\mathbf{5 1 , 3 0}$ & $\mathbf{1 7 , 1 0}$ \\
\hline
\end{tabular}

TABLE 4. European Democracies: Motivations of Patronage (\%)

\begin{tabular}{lcccc}
\hline Country & Control & Reward & $\begin{array}{c}\text { Both Control } \\
\text { and Reward }\end{array}$ & Other \\
\hline GREECE & 24 & 18 & 58 & 00 \\
AUSTRIA & 75 & 00 & 18 & 07 \\
ITALY & 38 & 00 & 62 & 00 \\
GERMANY & 47 & 00 & 50 & 03 \\
HUNGARY & 50 & 03 & 47 & 00 \\
BULGARIA & 39 & 12 & 39 & 00 \\
SPAIN & 40 & 04 & 51 & 05 \\
CZECH REP. & 66 & 10 & 24 & 00 \\
IRELAND & 04 & 25 & 50 & 21 \\
PORTUGAL & 29 & 07 & 51 & 12 \\
NORWAY & 73 & 00 & 22 & 05 \\
ICELAND & 34 & 16 & 50 & 00 \\
DENMARK & 24 & 00 & 00 & 76 \\
NETHERLANDS & 31 & 03 & 43 & 18 \\
UK & 88 & 00 & 07 & $\mathbf{1 0 . 8}$ \\
EUROPEAN MEAN & $\mathbf{4 4 . 2}$ & $\mathbf{0 6 . 9}$ & $\mathbf{3 8 . 1}$ & \\
\hline
\end{tabular}

